\title{
DAMPAK POSISI DUDUK PEMBATIK TULIS TERHADAP RISIKO KESEHATAN DAN PENGENDALIANNYA
}

\author{
Sumardiyono $^{1 *}$, Reni Wijayanti \\ ${ }^{1}$ Fakultas Kedokteran, Universitas Sebelas Maret Surakarta \\ *Email: sumardiyono@staff.uns.ac.id \\ ${ }^{2}$ Fakultas Kedokteran, Universitas Sebelas Maret Surakarta \\ Email: reni31073@gmail.com
}

\begin{abstract}
ABSTRAK
Pekerja pembatik tulis dengan posisi kerja duduk yang tidak ergonomis karena menggunakan "dingklik" sebagai tempat duduk dapat menyebabkan risiko kesehatan kerja berupa gangguan muskuloskeletal. "Dingklik" merupakan tempat duduk yang relatif pendek, kecil dan tanpa sandaran. Tujuan pengabdian kepada masyarakat ini untuk menilai risiko bahaya kesehatan kerja pada posisi duduk pembatik tulis dan mendesain kursi kerja pembatik yang ergonomis dalam rangka menurunkan gangguan muskuloskeletal pembatik tulis. Metode pengabdian kepada masyarakat yang digunakan adalah observasi langsung pada pembatik ketika melakukan pekerjaannya, pengukuran antropometri sesuai dimensi tubuh yang diperlukan untuk mendesain kursi pembatik, mendesain kursi pembatik ergonomis, dan uji coba kursi hasil rancangan. Uji coba dilakukan dengan menilai postur kerja menggunakan metode Rapid Upper Limb Assessment (RULA) dan penilaian keluhan gangguan muskuloskeletal menggunakan kuesioner Nordic Body Map (NBM) yang dilakukan terhadap 20 orang pembatik. Hasil pengabdian adalah kursi pembatik hasil rancangan dapat menurunkan grand skor RULA dari 5 (level risiko 3) menjadi 3 (level risiko 2), dan berdasarkan skor NBM, dapat menurunkan tingkat gangguan muskuloskeletal dari Tingkat Gangguan Sedang menjadi Tingkat Gangguan Rendah. Kesimpulan dari pengabdian ini adalah penggunaan kursi ergonomis dapat menurunkan gangguan muskuloskeletal pembatik tulis.
\end{abstract}

Kata kunci: posisi duduk, gangguan muskuloskeletal, kursi ergonomis, pembatik tulis

\section{PENDAHULUAN}

Kota Surakarta dikenal sebagai penghasil kain batik, yang salah satunya berasal dari kampung batik Laweyan di Surakarta. Salah satu unggulan produk kampung batik Laweyan Surakarta adalah batik tulis. Pada umumnya proses produksi batik tulis adalah persiapan (mencuci kain), membuat motif batik dengan lilin/malam, yang dilakukan dengan canting, perwarnaan; dan tahap menghilangkan lilin/malam dari kain (melorod). Pada saat melakukan proses membuat motif batik menggunakan canting, pekerja banyak mengabiskan waktu kerja dengan posisi duduk, seperti pada gambar 1 .

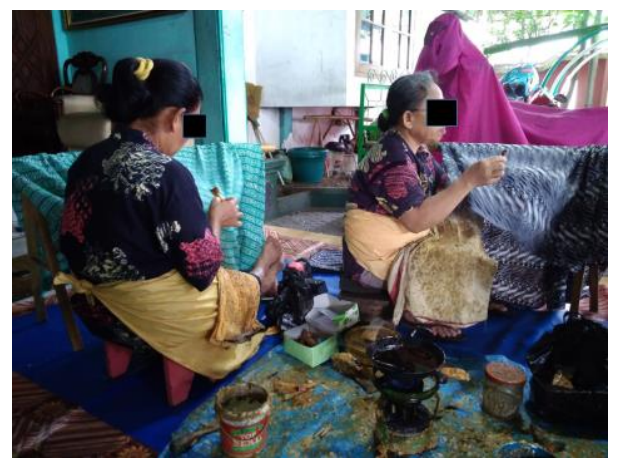

Gambar 1. Posisi kerja pembatik tulis 
Pada gambar 1, pengabdi dapat mendeskripsikan posisi kerja yang tidak ergonomis berdasarkan hasil identifikasi berupa tidak ada sandaran punggung sehingga punggung tidak bisa rileks (agak membungkuk), lutut kaki tidak bisa ditekuk 90 derajat (tempat duduk terlalu rendah), tidak ada sandaran tangan yang dapat melelahkan tangan, dan waktu kerja yang lama untuk posisi tersebut (pekerja bekerja 8 jam per hari dengan 1 jam istirahat). Dengan demikian, posisi kerja pembatik tersebut tidak ergonomis sehingga dapat menyebabkan risiko mengalami penyakit akibat pekerjaan.

Menurut Muliani (2008), kondisi pekerja yang menghabiskan waktu kerja dengan posisi duduk yang tidak ergonomis dapat menyebabkan ketegangan otot yang kronis. Dalam penyelesaian produknya, satu kain batik tulis memakan waktu yang cukup lama (tiga sampai lima hari) dengan waktu kerja 8 jam per hari, istirahat 1 jam. Dalam kurun waktu tersebut pekerja bekerja secara terus-menerus dengan posisi tidak ergonomis (membungkuk) yaitu duduk menggunakan dingklik atau kursi kecil tanpa sandaran. Posisi tersebut berbahaya karena mengakibatkan gangguan muskuloskeletal. Hasil penelitian Anjani et al. (2013) mengenai Musculosceletal Disorders (MSDs) menunjukkan sebanyak 67,7\% kasus menimpa pembatik yang mengalami keluhan MSDs di bagian leher, punggung bagian kanan, dan pinggang.

Sehubungan dengan hal tersebut, maka dirasa perlu untuk merubah posisi kerja pembatik yang tidak ergonomis menjadi ergonomis, karena menurut Wignjosobroto (2006), masalah gangguan muskuloskeletal dapat dikendalikan berdasarkan pendekatan ergonomi, sehingga didapatkan kinerja optimal ketika fasilitas kerja dirancang dan disesuaikan dengan ukuran antropometri pekerja agar masalah cedera dan penyakit akibat kerja dapat dikurangi, bahkan dihindarkan. Oleh karena itu, tujuan pengabdian kepada masyarakat ini untuk menilai risiko bahaya kesehatan kerja pada posisi duduk pembatik dan mendesain kursi kerja pembatik yang ergonomis dalam rangka menurunkan gangguan muskuloskeletal.

\section{METODE PELAKSANAAN PKM}

Makalah ini ditulis berdasarkan hasil kegiatan pengabdian kepada masyarakat Skema IbM Program Kemitraan Masyarakat (PKM) Tahun Anggaran 2018 yang didanai berdasarkan sumber dana PNBP Universitas Sebelas Maret tahun 2018, berjudul 'Desain "Kurgonomis" Bagi Wanita Pembatik Tulis'. Dasar pemikiran dari kegiatan pengabdian kepada masyarakat ini adalah hasil observasi posisi kerja pembatik tulis yang tidak ergonomis ketika menggunakan "dingklik" sebagai tempat duduk. Contoh gambar dingklik tersaji pada gambar 2.

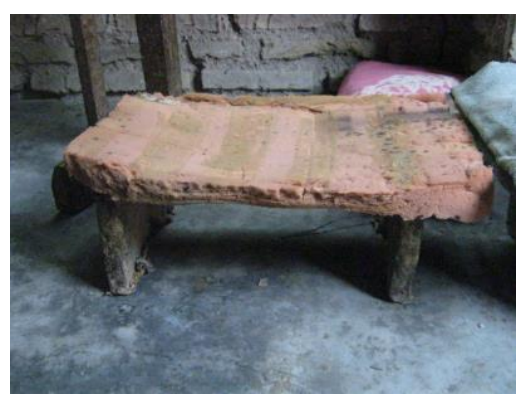

Gambar 2. "Dingklik"

Luaran utama dari kegiatan pengabdian kepada masyarakat ini adalah pembuatan kursi ergonomis untuk pembatik tulis (Gambar 3), yang sudah diujicobakan penggunaannya pada para pembatik tulis. 


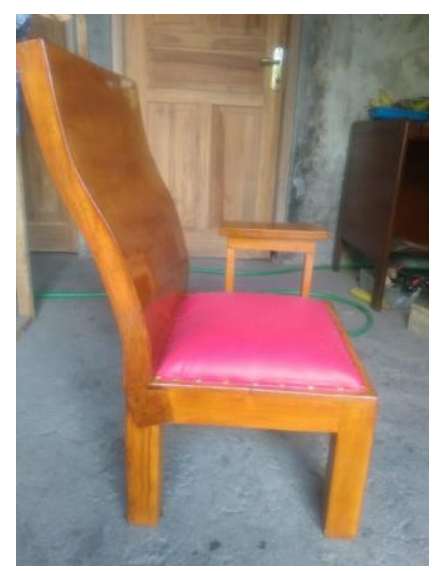

Gambar 3. Kursi Ergonomis hasil rancangan Pengabdian kepada Masyarakat

Pembuatan kursi ergonomis ini bertujuan untuk merubah posisi kerja pembatik yang sebelumnya duduk menggunakan "dingklik" diganti dengan menggunakan kursi ergonomis hasil rancangan yang diharapkan dapat menurunkan tingkat gangguan muskuloskeletal pembatik tulis. Dalam kegiatan pengabdian kepada masyarakat ini, tim pengabdi melakukan evaluasi dengan melakukan penilaian risiko ergonomi menggunakan metode Rapid Upper Limb Assessment (RULA) dan penilaian keluhan gangguan muskuloskeletal menggunakan Nordic Body Map (NBM) yang dinilai pada saat masih menggunakan "dingklik" (gambar 1) ketika membatik dan pada saat menggunakan kursi hasil rancangan pengabdian kepada masyarakat (gambar 2), dengan rentang waktu satu bulan sejak pemakaian kursi hasil rancangan.

Untuk menentukan dimensi kursi hasil rancangan pengabdian kepada masyarakat, tim pengabdi melakukan pengukuran antropometri para pembatik. Sebagai dasar perancangan digunakan prinsip ukuran nilai individu ekstrim menggunakan persentil 5\% dan 95\%. Dimensi ukuran tubuh dan penggunaan untuk rancangan kursi ergonomis seperti tersaji pada tabel 1.

\section{Tabel 1. Dimensi ukuran tubuh dan penggunaan untuk rancangan kursi ergonomis}

\begin{tabular}{|c|c|c|c|c|}
\hline No. & Dimensi tubuh & Rancangan kursi & Persentil & Ukuran kursi $(\mathrm{cm})$ \\
\hline 1. & Tinggi bahu duduk & Tinggi sandaran punggung & $95 \%$ & 47,0 \\
\hline 2. & $\begin{array}{l}\text { Panjang lekuk lutut s/d proyeksi } \\
\text { garis punggung }\end{array}$ & Panjang tempat duduk & $5 \%$ & 39,7 \\
\hline 3. & Tinggi lekuk lutut s/d telapak kaki & Tinggi kursi & $5 \%$ & 28,7 \\
\hline 4. & Lebar pinggul & Lebar kursi & $95 \%$ & 43,8 \\
\hline 5. & Tinggi siku duduk & Tinggi sandaran tangan & $5 \%$ & 16,5 \\
\hline 6. & Panjang lengan bawah & Panjang sandaran tangan & $95 \%$ & 24,3 \\
\hline 7. & Tebal lengan bawah & Lebar sandaran tangan & $95 \%$ & 9,3 \\
\hline
\end{tabular}

Analisis data hasil pengabdian terhadap penilaian posisi kerja dengan metode RULA dan penilaian gangguan muskuloskeletal dengan menggunakan NBM dilakukan secara deskriptif.

\section{HASIL DAN PEMBAHASAN}

Berdasarkan hasil observasi, dimensi "dingklik" cukup kecil dengan ukuran rata-rata adalah panjang $34,8 \mathrm{~cm}$, lebar $21,9 \mathrm{~cm}$, tinggi $18,2 \mathrm{~cm}$, tanpa sandaran punggung dan tanpa sandaran tangan. Penggunaan "dingklik" oleh pembatik ketika membatik menjadikan postur dan posisi kerja tidak ergonomis. Penilaian kergonomisas postur dan posisi kerja pembatik tulis digunakan 
metode RULA, dilakukan dengan mengambil gambar posisi kerja karyawan menggunakan kamera digital, dan selanjutnya dari gambar yang diambil di ukur sudut postur kerja pada bagian-bagian yang ingin diukur (Oesman et al., 2012). Hasil penelitian Oesman et al. (2012) pada pembatik menunjukkan jumlah responden dengan status risiko tinggi adalah $22 \%$, level sedang 56\% dan level ringan adalah 22\%. Hal tersebut karena sikap dan posisi kerja yang tidak alamiah dimana bagian-bagian tubuh responden pada saat bekerja bergerak menjauhi posisi badan seperti pergerakan tangan terangkat saat mencanting, punggung terlalu membungkuk dan memuntir dan leher menekuk atau memuntir. Sedangkan faktor lainnya adalah desain kursi yang digunakan untuk duduk pada saat membatik/mencanting tidak ergonomis.

Hasil penilaian postur kerja pembatik tulis menggunakan metode RULA pada pengabdian masyarakat ini tersaji pada tabel 2 (pekerja menggunakan "dingklik") dan tabel 3 (pekerja menggunakan kursi hasil rancangan).

Tabel 2. Penilaian RULA pembatik tulis menggunakan "dingklik"

\begin{tabular}{|c|c|c|c|c|}
\hline Gambar & Pengukuran Bagian tubuh & Skor & Skor Gabungan & $\begin{array}{c}\text { Grand } \\
\text { Skor }\end{array}$ \\
\hline 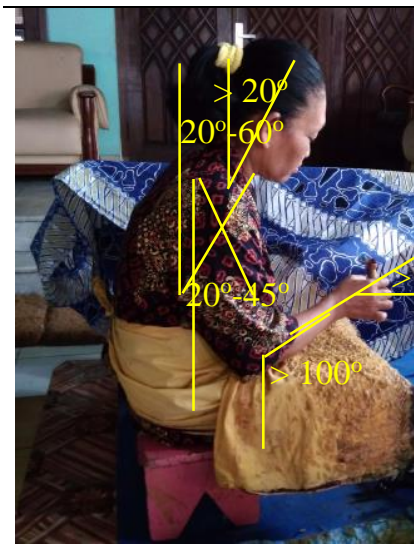 & $\begin{array}{l}\text { Grup A } \\
\text { 1. Sudut lengan atas: Fleksi } 20^{\circ}- \\
45^{\circ} \\
\text { 2. Lengan bawah: Fleksi }>100^{\circ} \\
\text { 3. Pergelangan tangan: Fleksi }> \\
15^{\circ} \text { dan pergelangan devisiasi } \\
\text { 4. Pergelangan tangan memuntir } \\
\text { Grup B } \\
\text { 1. Leher: Fleksi }>20^{\circ} \\
\text { 2. Badan: Fleksi } 20^{\circ}-60^{\circ} \\
\text { 3. Kaki }\end{array}$ & $\begin{array}{l}2 \\
2 \\
3 \\
1 \\
3 \\
3 \\
1\end{array}$ & $\begin{array}{l}\text { Skor Postur } \\
\text { Grup A = 3 } \\
\text { Bekerja statis }> \\
1 \text { menit = +1 } \\
\text { Grup C: } \\
3+1=4 \\
\text { Skor Postur } \\
\text { Grup B = 4 } \\
\text { Bekerja statis > } \\
1 \text { menit = +1 } \\
\text { Grup D: } \\
4+1=5\end{array}$ & 5 \\
\hline
\end{tabular}

\section{Tabel 3. Penilaian RULA pembatik tulis menggunakan "Kursi Hasil Rancangan"}

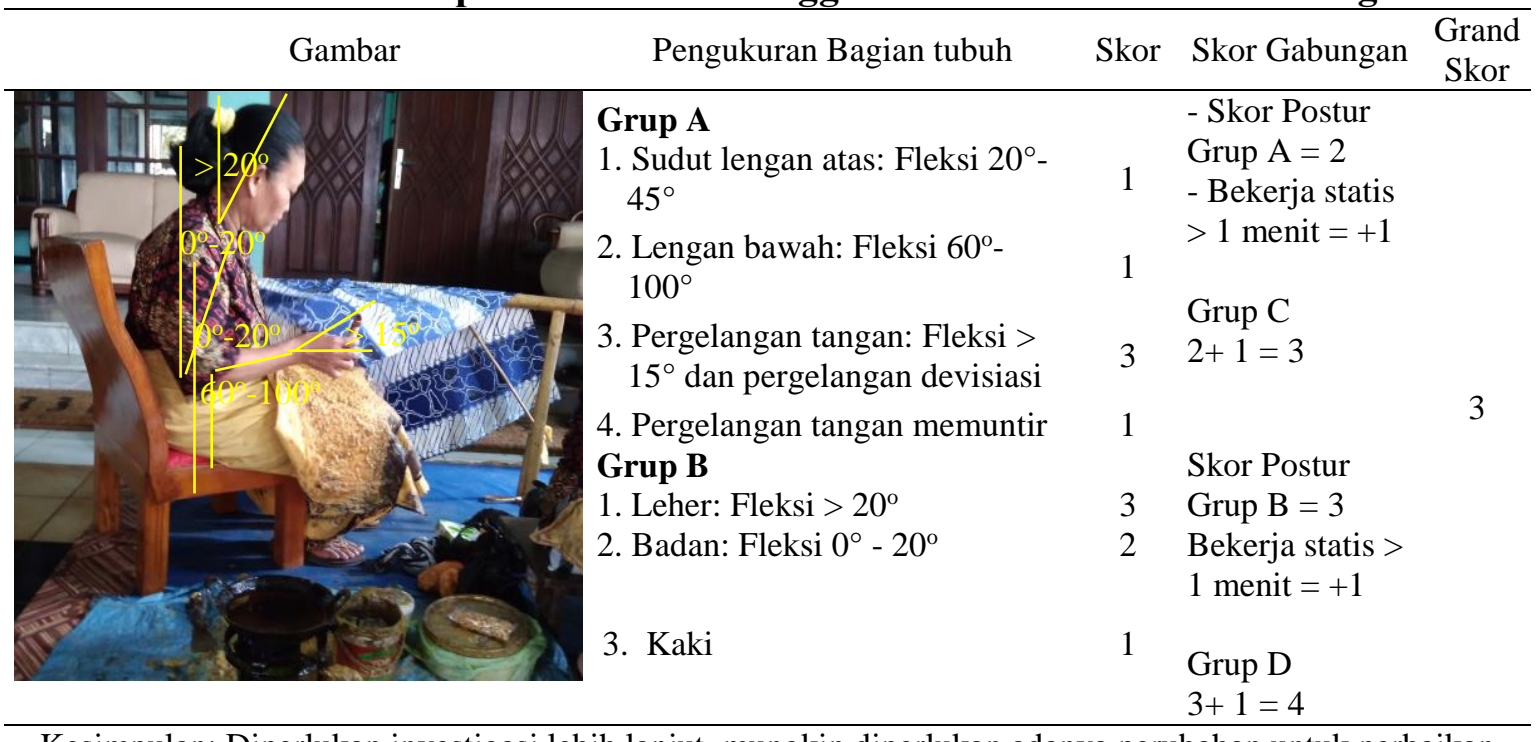

Kesimpulan: Diperlukan investigasi lebih lanjut, mungkin diperlukan adanya perubahan untuk perbaikan sikap kerja. 
Pada pemakaian kursi pembatik hasil rancangan tersebut dapat menurunkan grand skor RULA dari 5 menjadi 3. Makna dari grand skor RULA, menurut Tarwaka (2010), dapat dilihat pada tabel 4.

\section{Tabel 4. Tingkat Aksi yang diperlukan berdasarkan Grand Skor RULA}

Level Tingkat Aksi dari RULA

1 Apabila grand skor adalah 1 atau 2, tidak ada masalah dengan postur tubuh selama kerja.

2 Apabila grand skor adalah 3 atau 4, diperlukan investigasi lebih lanjut, mungkin diperlukan adanya perubahan untuk perbaikan sikap kerja.

3 Apabila grand skor adalah 5 atau 6, diperlukan adanya investigasi dan perbaikan segera.

4 Apabila grand skor adalah $7^{+}$, diperlukan adanya investigasi dan perbaikan secepat mungkin.

Sumber: Tarwaka, 2010.

Dengan merujuk pada tabel 4, maka nilai grand skor RULA sebesar 5 (ketika pekerja menggunakan "dingklik") berarti tingkat risikonya adalah level 3 atau diperlukan adanya investigasi dan perbaikan segera. Ketika pekerja menggunakan kursi ergonomis hasil rancangan dengan nilai grand skor RULA sebesar 3 atau diperlukan investigasi lebih lanjut, mungkin diperlukan adanya perubahan untuk perbaikan sikap kerja berarti tingkat risikonya menurun menjadi level 2. Dengan demikian penggunakan kursi ergonomis madapt menurunkan tingkat risiko berdasarkan skor RULA dari level 3 menjadi level 2. Walaupun sudah bisa menurunkan, namun masih belum mencapai skor 1 (Tidak ada masalah dengan postur tubuh selama bekerja).

Pada grand Skor RULA sebesar 3 atau diperlukan investigasi lebih lanjut (ketika menggunakan kursi hasil rancangan), maka investigasi lebih lanjut yang dimaksud dalam pengabdian kepada masyarakat ini adalah dengan memperhatikan tinggi "gawangan" (tempat meletakkan kain yang di"temboki" "malam" dengan menggunakan canting oleh pekerja) yang terlalu rendah, sehingga seperti terlihat dari kedua gambar pada tabel 1 dan tabel 2 menunjukkan bahwa sebenarnya sudah ada perbaikan tempat duduk, namun karena "gawangan" belum ditinggikan (tinggi "gawangan" awal $55 \mathrm{~cm}$ ), maka terlihat pekerja masih bermasalah pada posisi leher karena posisi menunduk. Oleh karena itu, pengabdi menyarankan untuk meninggikan "gawangan" menjadi $75 \mathrm{~cm}$, seperti tersaji pada gambar 4 .

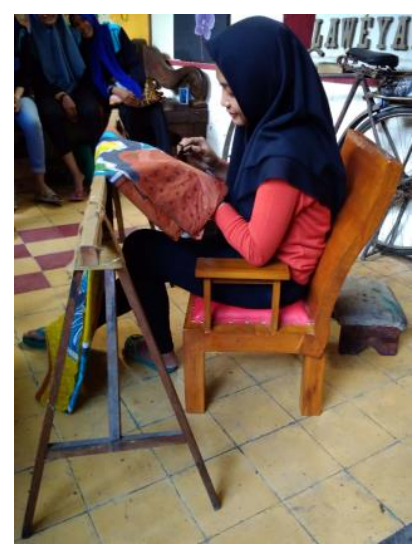

Gambar 4. Penyesuaian kursi hasil rancangan terhadap tinggi "gawangan" 
Pada gambar 4 terlihat bahwa dengan meninggikan "gawangan" maka pekerja tidak terlalu menunduk sehingga dapat menurunkan skor RULA untuk penilaian leher, serta pekerja dapat memanfaatkan sandaran tangan agar kelelahan pada tangan dapat tereduksi.

Penilaian ergonomi dengan menggunakan RULA ini lebih tepat untuk posisi berdiri, sehingga penggunaan skor RULA dalam pengabdian masyarakat ini masih ada kelemahannya. Untuk itu, pengabdi juga memberikan penilaian lain dengan menggunakan kuesioner Nordic Body Map (NBM). Kuesioner NBM adalah metode yang digunakan untuk menilai tingkat keparahan (severity) atas terjadinya gangguan pada otot-otot skeletal (Tarwaka, 2010). Nordic Body Map meliputi 28 bagian otot-otot skeletal pada kedua sisi tubuh kanan dan kiri yang dimulai dari anggota tubuh bagian atas yaitu otot leher sampai dengan bagian paling bawah yaitu otot pada kaki. Melalui kuesioner Nordic Body Map dapat diketahui bagian-bagian otot mana saja yang mengalami gangguan kenyerian atau keluhan. Penilaian menggunakan 4 skala Likert, dengan definisi operasional yaitu Skor 1 (tidak sakit) yaitu tidak ada keluhan/kenyerian atau tidak ada rasa sakit sama sekali, Skor 2 (agak sakit) yaitu dirasakan adanya sedikit keluhan atau kenyerian pada otot skeletal, Skor 3 (sakit) yaitu responden merasakan adanya keluhan/kenyerian atau sakit pada otot skeletal, Skor 4 (sangat sakit) yaitu responden merasakan keluhan sangat sakit atau sangat nyeri pada otot skeletal. Total skor individu dari 28 bagian otot skeletal menyatakan kategori tingkat risiko seperti tersaji pada tabel 5.

Tabel 5. Klasifikasi tingkat risiko otot skeletal berdasarkan total skor individu

\begin{tabular}{ccll}
\hline $\begin{array}{c}\text { Tingkat } \\
\text { Aksi }\end{array}$ & $\begin{array}{c}\text { Total Skor } \\
\text { Individu }\end{array}$ & Tingkat Risiko & \multicolumn{1}{c}{ Tindakan Perbaikan } \\
\hline 1 & $28-49$ & Rendah & Belum diperlukan adanya tindakan perbaikan \\
2 & $50-70$ & Sedang & Mungkin diperlukan tindakan di kemudian hari \\
3 & $71-91$ & Tinggi & Diperlukan tindakan segera \\
4 & $92-112$ & Sangat Tinggi & Diperlukan tindakan menyeluruh sesegera mungkin \\
\hline
\end{tabular}

Sumber: Tarwaka, 2010.

Dalam penilaian keluhan gangguan muskuloskeletal untuk mengevaluasi efektivitas kursi hasil rancangan, jumlah responden yang digunakan dalam penilaian keluhan gangguan muskuloskeletal adalah 20 orang. Ringkasan hasil penilaian keluhan gangguan muskuloskeletal pada pembatik yang menggunakan "dingklik" dan sesudah menggunakan kursi hasil rancangan seperti tersaji pada tabel 6 .

Tabel 6. Hasil penilaian keluhan gangguan muskuloskeletal menggunakan NBM

\begin{tabular}{lccccc}
\hline $\begin{array}{c}\text { Kategori } \\
\text { Skor NBM }\end{array}$ & "Dingklik" & $\begin{array}{c}\text { Tingkat Risiko } \\
\text { "Dingklik" }\end{array}$ & $\begin{array}{c}\text { "Kursi } \\
\text { Rancangan" }\end{array}$ & $\begin{array}{c}\text { Tingkat Risiko "Kursi } \\
\text { Rancangan" }\end{array}$ & $\begin{array}{c}\text { Reduksi Skor } \\
\text { NBM }\end{array}$ \\
\hline Terendah & 51 & Sedang & 30 & Rendah & 21 \\
Tertinggi & 66 & Sedang & 46 & Rendah & 20 \\
Rerata & 55,4 & Sedang & 36,0 & Rendah & 19,4 \\
\hline
\end{tabular}

Tabel 6 menunjukkan bahwa tingkat risiko gangguan muskuloskeletal pekerja dengan menggunakan "dingklik" sebagai tempat duduk memiliki tingkat risiko "Sedang" dengan skor rerata NBM adalah 55,4 dan tingkat risiko gangguan muskuloskelatal penggunaan kursi hasil 
rancangan pengabdian adalah "Rendah" dengan rerata skor NBM adalah 36,0. Dengan demikian penggunaan kursi ergonomis hasil rancangan pengabdian masyarakat dapat menurunkan rerata skor NBM sebesar 19,4 atau dapat menurunkan gangguan muskuloskeletal dari tingkat risiko kategori "Sedang" menjadi "Rendah".

Refrensi hasil penelitian sebelumnya, terhadap gangguan pada sistem muskuloskeletal (keluhan pada bagian-bagian otot skeletal yang dirasakan oleh seseorang mulai dari keluhan sangat ringan sampai sangat sakit), dapat dikelompokan menjadi dua, yaitu keluhan sementara (reversible) atau keluhan otot yang terjadi pada saat otot menerima beban statis, dan keluhan menetap (persisten) atau keluhan otot yang bersifat menetap (Tarwaka et al., 2004). Aktivitas kerja pada proses pembatikan yang dilakukan dengan cara manual menggunakan alat-alat tradisional dengan posisi duduk menggunakan "dingklik" dapat menimbulkan gangguan muskuloskeletal. Menurut Ayoub dan Woldstad (1999), keluhan sistem muskuloskeletal merupakan masalah dalam suatu industri yang disebabkan oleh sarana kerja yang tidak memadai, aktivitas yang bersifat repetitif, rancangan alat dan peralatan yang tidak sesuai dengan pemakai, organisasi kerja yang tidak efisien, jadwal istirahat yang tidak teratur dan sikap kerja yang tidak alamiah. Sumardiyono et al. (2014) menyatakan bahwa pekerja dengan menggunakan "dingklik" mengalami MSDs yang lebih tinggi dibandingkan dengan sesudah pekerja menggunakan kursi yang ergonomis.

\section{KESIMPULAN DAN SARAN}

\section{Kesimpulan}

Risiko bahaya kesehatan kerja pekerja pembatik tulis dalam posisi duduk menggunakan "dingklik" yang tidak ergonomis adalah gangguan muskuloskeletal (MSDs). Penggunaan kursi ergonomis dapat menurunkan tingkat gangguan muskuloskeletal dari tingkat "Sedang" menjadi tingkat "Rendah".

\section{Saran}

Pemilik industri batik menyediakan kursi ergonomis, dan para pembatik tulis membiasakan diri menggunakan kursi ergonomis.

\section{Ucapan Terima Kasih (Acknowledgement)}

Penulis mengucapkan terima kasih kepada:

1. Kepala Lembaga Penelitian dan Pengabdian Kepada Masyarakat (LPPM) Universitas Sebelas Maret yang telah memberikan tugas dan pendanaan kegiatan pengabdian kepada masyarakat.

2. Pimpinan Perusahaan Batik Mahkota dan Batik Merak Manis Surakarta yang telah memberikan ijin lokasi kegiatan.

3. Aprilia Kusuma Dewi, Rizka Fitri Ardiani, dan Galuh Larasati selaku mahasiswi Program D3 Hiperkes dan Keselamatan Kerja, Fakultas Kedokteran Universitas Sebelas Maret, yang telah membantu kegiatan pengabdian kepada masyarakat ini.

\section{REFERENSI}

Agustin, C.P.M., Mardiana, Budiono, I.B. (2013). Hubungan Masa Kerja dan Sikap Kerja dengan Kejadian Sindrom Karpal pada Pembatik CV. Pusaka Beruang Lasem, Unnes Journal of Public Health, 2(2), 74-80. 
Anjani, S., Hidayat, R., Adlan, Y.A., Suzianti, A., dan Hapsari, R.T.V. (2013). Design of Ergonomic Stool (Dingklik) for Batik Crafters. International Journal of Technology, 4(3), 299-305.

Ayoub, M.M. and Woldstad, J.C. (1999). Models in Manual Materials Handling. Industrial and Management Systems Engineering Faculty Publications. Available at: https://digitalcommons.unl.edu/cgi/viewcontent.cgi? article=1013\&context=imsefacpub

Muliani, R. (2008). Tinjauan Kesesuaian Penggunaan Kursi Kantor Berdasarkan Penggunaan Data Pengukuran Antropometri Statis Duduk Karyawan di Main Office PT. X Tahun 2008, Skripsi, FKM UI, Depok.

Oesman, T.I., Yusuf, M., dan Irawan, L. (2012). Analisis Sikap dan Posisi Kerja pada Perajin Batik Tulis di Rumah Batik Nakula Sadewa, Sleman. Seminar Nasional Ergonomi 2012, Yogyakarta, 95-103.

Sumardiyono, Probandari, A., Hanim, D., Handayani, S., and Susilowati, I.H. (2014). Effectiveness of Ergonomic Chair against Musculoskeletal Disorders in Female Batik Workers of Sragen District, Makara J. Health Res., 18(2), 95-102.

Tarwaka, Bakri, S.H.A., dan Sudiajeng, L. (2004). Ergonomi Untuk Keselamatan, Kesehatan Kerja dan Produktivitas, Ed. 1, Uniba Press, Surakarta.

Tarwaka, (2010), Ergonomi Industri, Dasar-Dasar Pengetahuan Ergonomi dan Aplikasi di Tempat Kerja, Ed. 1, Surakarta, Harapan Press, p. 338.

Wignjosoebroto, S. (2006). Pengantar Teknik dan Manajemen Industri, Guna Widya, Surabaya. 